\title{
DNA content and marker expression in human glioma explants
}

\author{
R. D. Davenport and P. E. McKeever \\ University of Michigan Medical School, Department of Pathology, Medical Science I M5240/0602, \\ 1500 E. Medical Center Dr., Ann Arbor, MI 48109-0602, USA
}

Summary. Immunohistochemical studies of astrocytoma tissue have predominately shown fibronectin (FN) positivity restricted to vessels and glial fibrillary acidic protein (GFAP) positivity in the parenchyma. Cultured glioma cell lines, however, express both FN and GFAP. We measured the DNA content of explants of gliomas to determine if the ploidy of the FN-positive and GFAP-positive cells differed. Thirtythree explants from four high grade gliomas were cultured on slides. FN and GFAP markers were determined by double immunofluorescence. The slides were stained by the Feulgen method, the explants relocated and the DNA content measured by microdensitometry using the CAS-100 instrument. Human leukocytes applied to the slides were used as a diploid standard. Eleven GFAP-positive explants were hyperdiploid and one hypodiploid. Five FN-positive explants were diploid, three hypodiploid and ten hyperdiploid. One FN-positive explant was biclonal with aneuploid subpopulations. Two hyperdiploid explants, each of which had monoclonal histogram patterns, expressed both FN and GFAP. We conclude that most FNpositive cells, in addition to GFAP-positive cells, from cultured gliomas represent neoplastic cells. These may be present in the tumor in low numbers or may result from marker switching in culture.

Key words: DNA - Glioma - Fibronectin - Glial fibrillary acidic protein - Cell culture

Cell culture is a powerful technique for investigating problems in tumor biology. However, it may yield results which are at odds with direct observations of histopathology. Cells cultured from human gliomas have been observed to express glial fibrillary acidic

Offprint requests to: $\mathrm{R}$. D. Davenport (address see above) protein (GFAP), a marker of astrocytes, as well as fibronectin (FN), a marker of mesenchymal cells (Bigner et al. 1981; Jones et al. 1982; Paetau et al. 1980a; Ponten and Westermark 1978; McKeever et al. 1987; Nishiguchi et al. 1985; McKeever and Chronwall 1984). Histological sections of gliomas stained for GFAP and FN almost always show GFAP in the tumor parenchyma and FN confined to the stroma (Chronwall et al. 1983; Bellon et al. 1985; Jones et al. 1982; Paetau et al. 1980 b; Bigami et al. 1972; Deck et al. 1978; Delpech et al. 1978; Eng and Rubinstein 1978). This raises the question of whether the FNpositive cells in culture are derived from the malignant cells or the stroma. To answer this question, we have determined the DNA content and marker expression of explant cultures from four high grade astrocytomas. Our results indicate that although some FN-positive cells in culture may come from benign stromal cells, most are derived from tumor cells.

\section{Methods}

Explant cultures of human astrocytomas were obtained from surgically resected tissue as previously described (McKeever et al. 1981; McKeever et al. 1987). Necrotic areas, visible blood vessels and any encapsulating material were cut away under sterile conditions so that homogeneous viable tumor tissue remained. This tissue was minced into approximately $1-\mathrm{mm}$ size pieces which were placed on Lab-Tek chamber slides (Lab-Tek, Miles Scientific, Naperville, IL, USA) in Ham's F10 medium with $10 \%$ fetal calf serum, from which remaining traces of FN were removed by absorption over a gelatine-agarose affinity column (Baldwin et al. 1985). The slides were placed in a wellhumidified incubator with $10 \% \mathrm{CO}_{2}$ at $37^{\circ} \mathrm{C}$. The culture medium was replaced weekly. Growth was checked periodically by phase microscopy and explants were harvested after 9-45 days of culture when sufficient growth was observed.

When the explants were harvested, the medium was discarded and the slides fixed immediately in methanol for $15 \mathrm{~min}$. The slides were allowed to air dry and human leukocytes were applied to one edge. The slides were washed in phosphatebuffered saline (PBS) for $15 \mathrm{~s}$ and flooded with 0.3\% Saponin plus $1 \mathrm{mM}$ EDTA in PBS (Sigma Chemical, St. Louis, MO, 
USA) for $2 \mathrm{~min}$. The slides were again washed with PBS, then $100 \mu \mathrm{l}$ of rabbit anti-GFAP (Accurate Chemical and Scientific Co., Westbury, NY, USA) were applied for $15 \mathrm{~min}$. After another PBS wash, $100 \mu \mathrm{l}$ of rhodamine-conjugated goat antirabbit IgG (Cappel Division of Cooper Biomedical, Malvern, PA, USA) at a dilution of 1:100 were applied to the slide for 15 min. After another PBS wash, $100 \mu \mathrm{l}$ of fluoresceinconjugated goat anti-human fibronectin (Cooper Biomedical, Malvern, PA) at a dilution of 1:50 were applied to the slide for 15 min. Slides were washed again in PBS, wet-mounted with distilled water, and examined for explant staining under a fluorescent microscope. Positivity was determined by comparison with positive and negative controls. Cell and tissue controls were the cultured cell lines U251 (GFAP +), U138 $(\mathrm{FN}+)$, human fibroblasts $(\mathrm{FN}+)$; and cryostat sections of brain tumor tissue (both GFAP + and FN + ) (Chronwall et al. 1983). Negative staining controls were made by deletion of the primary antibody in the staining procedure and by absorption with human FN (Chronwall et al. 1983). The position of each explant was marked on the back of the slide with indelible ink so that it could be relocated.

After immunofluorescent examination, slides were fixed in $10 \%$ neutral buffered formalin for $5 \mathrm{~min}$ and stained by the Feulgen procedure as follows. Slides were placed in $5 \mathrm{M} \mathrm{HCl}$ at room temperature for $60 \mathrm{~min}$. Slides were transferred to stain solution ( $375 \mathrm{mg}$ Azure $\mathrm{A}, 1.5 \mathrm{~g} \mathrm{~K}_{2} \mathrm{~S}_{2} \mathrm{O}_{5}$ in $75 \mathrm{ml}$ of $0.1 \mathrm{M} \mathrm{HCl}$ ) for $2 \mathrm{~h}$. Slides were rinsed three times for $5 \mathrm{~min}$ in a solution of $0.2 \mathrm{~g} \mathrm{~K}_{2} \mathrm{~S}_{2} \mathrm{O}_{5}$ in $300 \mathrm{ml}$ of $0.05 \mathrm{M} \mathrm{HCl}$. Slides were washed in distilled water for $5 \mathrm{~min}$, dehydrated in ethanol, cleared in xylene and coverslipped. A standard slide with Rainbow Trout erythrocytes (Cell Analysis Systems, Lombard, IL, USA) was included in each stain batch.

DNA analysis was performed with a Cell Analysis Systems CAS-100 image analysis system. The trout erythrocytes and human leukocytes were used as DNA standards. Each explant was relocated and the integrated optical density of the Feulgenstained nuclei was measured. One hundred cells or all cells in each explant were measured, whichever was less. Degenerating cells without a clear chromatin structure were not measured. The DNA index (DNAI) was calculated for the first modal peak of the histogram of nuclear DNA content, relative to the diploid value determined from the standards. The percentage of cells in the $S$ plus $\mathrm{G}_{2} / \mathrm{M}$ phases of the cell cycle was calculated for each explant (except one explant which was biclonal).

Gliomas were classified in accord with descriptions by Rubinstein (Rubinstein et al. 1972) and of Burger and Vogel (Burger and Vogel 1982). Gliomas were graded as described by Fulling and Nelson (Fulling and Nelson 1984). Correlation with the Kernohan grading system (Kernohan and Sayre 1952) was as described by Zulch (Zulch 1979). No attempt to sample a specific type of glioma was made other than to use cases which grew well enough as explants in culture to support the study.

\section{Results}

Cases 1 and 4 were each glioblastoma multiforme (Kernohan grade of IV). Histological sections of both neoplasms contained substantial coagulation necrosis and minimal proliferation of vascular cells. Both neoplasms contained regions of hypercellularity, mitoses and tumor giant cells. There were more abnormal mitotic figures in case 4 than in case 1 .

Cases 2 and 3 were anaplastic astrocytomas (Kernohan grade of III). Both cases had regions of

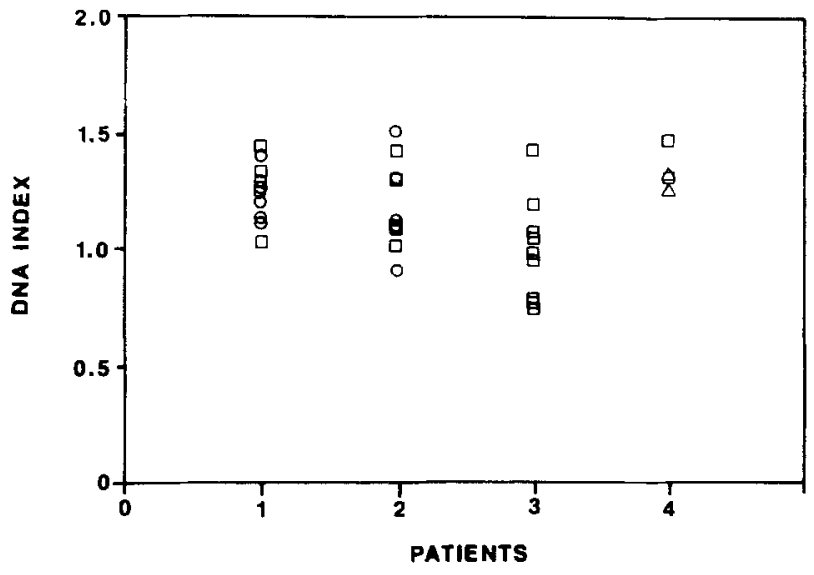

Fig. 1. Distribution of DNA index (DNAI) and marker expression of cultured explants from the four gliomas in this study. $\triangle$ Mixed, O GFAP, $\square$ FN

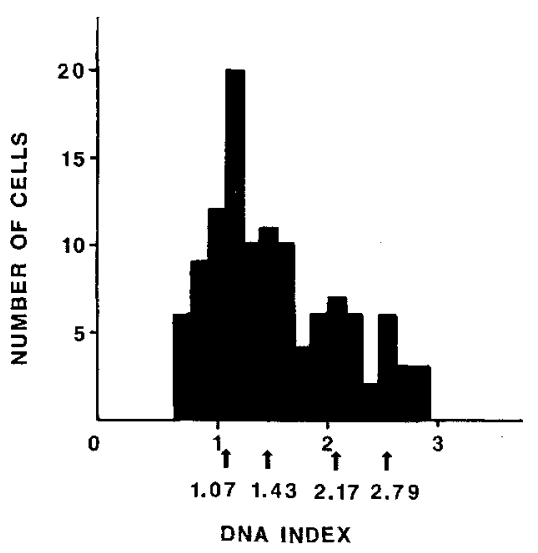

Fig. 2. Histogram of nuclear DNA content of a fibronectin(FN)positive explant with a biclonal pattern. The first and third peaks represent the $\mathrm{G}_{0} / \mathrm{G}_{1}$ and $\mathrm{G}_{2} / \mathrm{M}$ populations of one clone with DNAI $=1.07$. The second and fourth peaks are the $\mathrm{G}_{0} / \mathrm{G}_{1}$ and $\mathrm{G}_{2} / \mathrm{M}$ peaks of another clone with $\mathrm{DNAI}=1.43$

moderate and other regions of high cellular density. Gemistocytes predominated in some regions of case 2, but were rare in case 3 . There were a few mitoses in both cases. Case 2 also contained rare abnormal mitotic spindles. Nuclei from both cases were moderately pleomorphic and hyperchromatic, slightly less pleomorphic in case 3. Both had minimal proliferation of vascular cells and no regions of coagulation necrosis. Multinucleated cells were relatively common in case 2 and rare in case 3.

Thirty-three explant cultures were obtained from the four patients. Twelve explants were positive for GFAP, 19 were positive for FN and 2 were stained by both markers.

The DNAI of the explants is shown in Fig. 1. The DNAI ranged from 0.76 to 1.51 . All explants except one were monoclonal, as evidenced by a single $G_{0} / G_{1}$ 


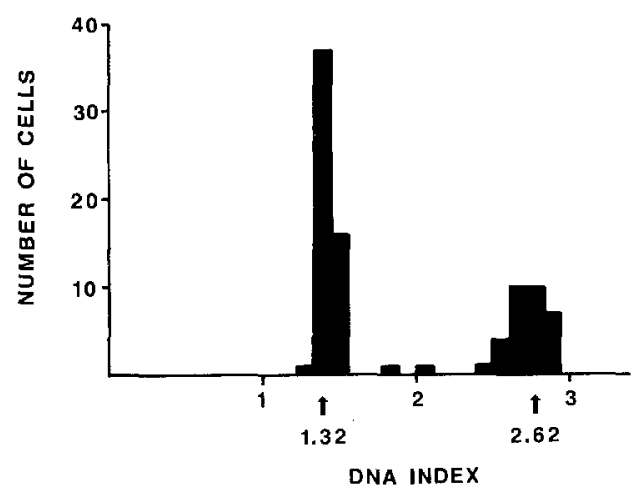

Fig. 3. Histogram of nuclear DNA content of a monoclonal explant, which was positive for both $\mathrm{FN}$ and glial fibrillary acidic protein. The major peak at 1.32 represents the $G_{0} / G_{1}$ population. The second peak at 2.62 , twice the DNA content of the base peak, represents the $G_{2} / M$ population

peak with a variable $S$ phase and $G_{2} / M$ peak. One FN-positive explant from patient 3 was biclonal (Fig. 2) with DNAIs of 1.07 and 1.43. Eleven GFAPpositive explants were hyperdiploid (DNAI $>1.05$ ), and one was hypodiploid (DNAI $=0.91)$. Ten FNpositive explants were hyperdiploid (DNAI $>1.05$ ), 5 were diploid $(0.95<$ DNAI $<1.05)$, and 3 were hypodiploid (DNAI < 0.95). Two explants, both from patient 4, were positive for both markers. These had DNAIs of 1.32 and 1.26 with monoclonal histogram patterns (Fig. 3). Eight GFAP-positive and 14 FNpositive explants had cells with DNA contents above the $\mathrm{G}_{2} / \mathrm{M}$ peak. There was no significant relationship between DNAI and percentage of cells in the S plus $\mathrm{G}_{2} / \mathrm{M}$ phases of the cell cycle. There was no significant difference between the means of the DNAIs of the FNpositive and GFAP-positive explants ( $t$-test $p>0.1)$.

\section{Discussion}

This study was undertaken to determine the relationship between marker expression, clonallity and DNA content in cultured cells obtained from human astrocytomas. All of the explants in this study, except one, had monoclonal patterns of DNA content. Evidence for monoclonallity was a single major peak $\left(\mathrm{G}_{0} /\right.$ $G_{1}$ ) with or without a minor peak at twice the DNA content $\left(G_{2} / M\right)$. Between these was a variable number of cells representing the $\mathrm{S}$ phase. This indicated that the cells of the explants growing in culture arose from a single original cell, or several cells having a common progenitor. One explant was biclonal, with two major $\mathrm{G}_{0} / \mathrm{G}_{1}$ peaks, indicating that it arose from more than one stem cell in culture.

The distribution of DNAI between the FN-positive and GFAP-positive explants was similar. The lack of a statistically significant difference between the means of the FN- and GFAP-positive explants is evidence that they belong to the same population. There were aneuploid explants which expressed each marker. There was a tendency for the explants with DNAI close to one to be FN-positive. There were also hypodiploid explants which expressed each marker. Although the explants with DNAI of unity may have arisen from benign stromal elements of the tumor, it is likely that the aneuploid explants originated from neoplastic cells. In tissue sections of gliomas the GFAP expression is found in the glial regions, whereas the FN expression is largely confined to the vasculature (Bellon et al. 1985; Schiffer et al. 1984; Jones et al. 1982). Positive FN staining has been reported, however, within the interstitium (Jones et al. 1982) and the extracellular matrix (Bellon et al. 1985) of astrocytomas. Our experience is that, if FN staining is observed at all in the parenchyma, it is in very rare cells (Chronwall et al. 1983). Since the cells involved in the vascular proliferation of high grade astrocytomas have been shown to be diploid, regardless of the ploidy of the astrocytic component (Davenport and McKeever 1987), overgrowth by vascular cells could not account for the presence of FN-positive explants with aneuploidy. In addition, the high proportion of FN-expressing explants observed (21 out of 33 ) would be improbable if they arose from the relatively infrequent FN-positive cells seen in tissue sections.

There were two explants in this study which had monoclonal DNA patterns and expressed both markers. Both of these were aneuploid. It is unlikely then that the FN-positive cells in these cases were benign stromal cells. These two explants, therefore, represent neoplastic cells with the capacity to express both FN and GFAP. Both cells from primary culture of astrocytomas and established glial cell lines have been shown to express FN (McKeever et al. 1981, 1987; McKeever and Chronwall 1984; Paetau et al. $1980 \mathrm{a}$; Jones et al. 1982; Ponten and Westermark 1978; Bigner et al. 1981; Nishiguchi et al. 1985). In addition, there is evidence that glioma cells may switch from GFAP expression to FN expression early in culture (McKeever and Chronwall 1984). Our findings could be explained by marker switching in culture or the presence of some $\mathrm{FN}$-positive neoplastic cells in the original tumor.

In this study there was diversity of nuclear DNA content among explants from the same tumor. Others have noted that there are multiple subpopulations within astrocytomas which differ in nuclear DNA content (Shapiro and Shapiro 1984; Hoshino et al. 1982; Shapiro et al. 1981). However, previous studies have not correlated DNA content with initial expression of well-defined protein markers in culture. These subpopulations also differ in phenotype such as 
tumorigenicity, resistence to chemotherapeutic agents and, as in this study, expression of mesenchymal markers. This heterogeneity has therapeutic and prognostic implications which will require further study.

It should be noted that the diploid explants in this study may in fact represent proliferations of neoplastic cells, because the measurement of nuclear DNA content probably underestimates the proportion of malignant cells. Cytogenetic studies have demonstrated diploid and near diploid cells from tissue and primary cell culture of gliomas which have numerical chromosome abnormalities, marker chromosomes and the presence of double minutes (Bigner et al. 1985). The cytophotometric measurements of DNA content would not necessarily detect these abnormalities, therefore explants within the diploid or near diploid range, whether GFAP- or FN-positive, may still have distinct cytogenetic abnormalities.

We conclude from this study that the neoplastic cells derived from cultured human astrocytomas have the capability of expressing FN. These may be present in low numbers in the original tumor or result from marker switching in culture.

\section{References}

Baldwin JR, McKeever PE, Booker TR (1985) Products of cultured neuroglial cells. II. The production of fibronectin by C6 glioma cells. Neurochem Res 10:601-610

Bellon G, Caulet T, Cam Y, Pluot M, Poulin G, Pytlinska M, Bernard MH (1985) Immunohistochemical localisation of macromolecules of the basement membrane and extracellular matrix of human gliomas and meningiomas. Acta Neuropathol (Berl) 66:245-252

Bignami W, Eng LF, Dahl D, Uyeda CT (1972) Localization of glial fibrillary acidic protein in astrocytes by immunofluorescence. Brain Res 43:429-435

Bigner DD, Bigner SH, Ponten J, Westermark B, Mahaley MS, Ruoslahti E, Herschman H, Eng LF, Wikstrand CJ (1981) Heterogeneity of genotypic and phenotypic characteristics of fifteen permanent cell lines derived from human gliomas. J Neuropathol Exp Neurol 40:201 - 229

Bigner SH, Bjerkvig R, Learum OD (1985) DNA content and chromosomal composition of malignant human gliomas. Neurol Clin 3:769-784

Burger PC, Vogel FS (1982) Surgical pathology of the nervous system and its coverings, 2nd edn. Wiley \& Sons, New York, pp 223-269

Chronwall BM, McKeever PE, Kornblith PL (1983) Glial and nonglial neoplasms evaluated on frozen section by double immunofluorescence for fibronectin and glial fibrillary acidic protein. Acta Neuropathol (Berl) 59:283-287

Davenport RD, McKeever PE (1987) Ploidy of endothelium in high grade astrocytomas. Anal Quant Cytol Histol 9:2529

Deck JHN, Eng LF, Bigbee J, Woodcock SM (1978) The role of glial fibrillary acidic protein in the diagnosis of central nervous system tumors. Acta Neuropathol (Berl) 42:183190
Delpech B, Delpech A, Vidard MN, Girard N, Tayot J, Clement JC, Creissard P (1978) Glial fibrillary acidic protein in tumors of the nervous system. Br J Cancer 37:33-40

Eng LF, Rubinstein LJ (1978) Contribution of immunohistochemistry to diagnostic problems of human cerebral tumors. J Histochem Cytochem 26:513-522

Fulling KH, Nelson JS (1984) Cerebral astrocytic neoplasms in the adult: contribution of histological examination to the assesment of prognosis. Semin Diagn Pathol 1:152-163

Hoshino T, Knebel KD, Rosenblum ML, Dougherty DV, Wilson CB (1982) Clonogenicity of multiple populations of human glioma cells in vitro sorted by DNA content. Cancer $50: 997-1002$

Jones TR, Ruoslahti E, Schold SC, Bigner DD (1982) Fibronectin and glial fibrillary acidic protein expression in normal human brain and anaplastic human gliomas. Cancer Res 42:168-177

Kernohan JW, Sayre GP (1952) Tumors of the central nervous system. Armed Forces Institute of Pathology, Washington, DC, pp $17-42$

McKeever PE, Chronwall BM (1984) Early switch in glial protein and fibronectin markers on cells during the culture of buman gliomas. Ann NY Acad Sci 435:457-459

McKeever PE, Hood TW, Varani J, Taren JA, Beierwaltes WH, Wahl R, Liebert M, Nguyen PK (1987) Products of cells cultured from gliomas. V. Cytology and morphometry of two cell types cultured from gliomas. J Natl Cancer Inst $78: 75-84$

McKeever PE, Quindlen E, Banks MA, Williams U, Kornblith PL, Laverson S, Greenwood MA, Smith B (1981) Biosynthesized products of cultured neuroglial cells. I. Selective release of proteins by cells from human astrocytomas. Neurology $31: 1445-1452$

Nishiguchi DJ, Stephens RE, Yates AJ (1985) Application of flow cytometry to analyses of cultured human glioma and fetal brain cells. J Neuropathol Exp Neurol 44:254-267

Paetau A, Mellstrom K, Westermark B, Dahl D, Haltia M, Vaheri A (1980a) Mutually exclusive expression of fibronectin and glial fibrillary acidic protein in cultured brain cells. Exp Cell Res 129:337-344

Paetau A, Mellstrom K, Vaheri A, Haltia M (1980b) Distribution of a major connective tissue protein, fibronectin, in normal and neoplastic human nervous tissue. Acta Neuropathol (Berl) $51: 47-51$

Ponten J, Westermark B (1978) Properties of human malignant glioma cells in vitro. Med Biol 56:184-193

Rubinstein LJ (1972) Tumors of the central nervous system. Armed Forces Institute of Pathology, Washington, DC, pp $7-50$

Schiffer D, Giordana MT, Mauro A, Migheli A (1984) GFAP, FVIII/RAg, laminin, and fibronectin in gliosarcomas: an immunohistochemical study. Acta Neuropathol (Berl) 63: $108-116$

Shapiro JR, Shapiro WR (1984) Clonal tumor cell heterogeneity. Prog Exp Tumor Res 27:49-66

Shapiro JR, Yung WA, Shapiro WR (1981) Isolation, karyotype and clonal growth of heterogeneous subpopulations of human malignant gliomas. Cancer Res $41: 2349-2359$

Zulch KL (1979) Histological typing of tumours of the central nervous system. World Health Organization, Geneva, pp $14-52$

Received March 3, 1987/Accepted April 30, 1987 